\title{
Epigenetic inactivation of the canonical wnt antagonist secreted frizzled-related protein 1 in hepatocellular carcinoma cells
}

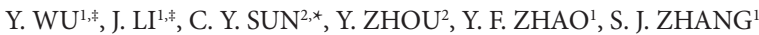

${ }^{1}$ Department of Hepatobiliary and Pancreatic Surgery, the First Affiliated Hospital of Zhengzhou University; Key Laboratory of Hepatobiliary and Pancreatic Surgery \& Digestive Organ Transplantation of Henan Province, Zhengzhou, Henan 450052, P. R. China; ${ }^{2}$ Department of Infectious Diseases, the First Affiliated Hospital of Zhengzhou University, Zhengzhou, Henan 450052, P. R. China

${ }^{*}$ Correspondence: changyusun@yahoo.com

${ }^{*}$ Contributed equally to this work.

Received November 7, 2011 / Accepted December 16, 2011

Secreted Frizzled-related protein 1 (sFRP1), as one of most important Wnt antagonists, is frequently silenced by promoter hypermethylation in many types of tumor, including hepatocellular carcinoma (HCC). In this study, we aimed to investigate whether restoration of sFRP1 affected HCC metastatic behavior.

sFRP1 mRNA expression and promoter methylation in HCC tissues and cell lines were examined using RT-PCR and methylation-specific PCR (MS-PCR), respectively. sFRP1 protein expression was assessed by Western Blot. We generated stable HCC cell line restoration of sFRP1 in HepG2 cells, which naturally do not express detectable sFRP1 mRNA. The effects of exogenous sFRP1 on HepG2 cell invasion were investigated using trans-well assay. Also the effects of sFRP1 re-expression on the $\beta$-catenin/T-cell factor-dependent transcription activity was measured by luciferase assay.

sFRP1 promoter methylation was frequently observed in HCC tissues (60\%) and cell lines (75\%). All samples with sFRP1 methylation showed down-regulation of sFRP1 expression in HCC cell lines. Demethylation treatment with 5-aza-20-deoxycytidine in HCC cells restored sFRP1 expression. Restoration of sFRP1 substantially impaired the invasive potentials of HepG2 cells. Moreover, exogenous sFRP1 caused significant decrease of $\beta$-catenin/T-cell factor-dependent transcription activity.

These findings demonstrate that sFRP1 silencing due to promoter hypermethylation is a major event during tumorigenesis. sFRP1 is also a negative modulator of canonical Wnt signaling, which could contribute to metastasis in HCC progression, thus providing a possible therapeutic strategy against HCC.

Key words: sFRP1, promoter hypermethylation, invasion, hepatocellular carcinoma

Hepatocellular carcinoma (HCC) is one of the most lethal human malignancies worldwide [1]. Incidence rates of HCC shows a sharp increase in China and other Asian countries over the last two decades [2-4]. Although great improvements in understanding of HCC biology and significant advances in surgical technology and therapy regimens over the last two decades, the molecular mechanisms of hepatocarcinogenesis is still poorly understood $[5,6]$. Therefore, clarification of molecular alterations is crucial to identify novel diagnostic and therapeutic targets, and will assist the development of novel therapeutic interventions for this deadly disease.

The Wingless-type (Wnt) signaling pathway is an ancient and highly conserved pathway which regulates diverse developmental processes (such as cell proliferation, invasion and adhesion) and plays important roles in multiple physiological and pathophysiological events $[7,8]$ Inactivation of Wnt signaling is regulated by couple of Wnt antagonists, including the Cerberus, Wnt inhibitory factor 1, secreted frizzledrelated protein (sFRP) and Dickkopf families, which directly bind to Wnts and subsequently inactivate both canonical and noncanonical signaling pathways [9]. It has been reported that loss of Wnt antagonists can cause aberrant activation of the Wnt pathway resulting in carcinogenesis through dysregulation of cellular proliferation and invasion. Aberrant activation of Wnt antagonists is also frequently observed in various human cancers with the genetic and epigenetic alterations [10-12].

As one of most important Wnt antagonists, sFRPs were widely studied in various types of cancer [13]. The sFRPs class 
includes sFRP1 to sFRP5. sFRP1 is a $35 \mathrm{kDa}$ secreted glycoprotein and localized to chromosome $8 \mathrm{p} 12-\mathrm{p} 11.1$, which is a high-frequent genetic alteration region in some tumors [1420]. Moreover, epigenetic down-regulation of sFRPs expression has been showed in tumors of various organs, including stomach [15], lung [16], colon [17] and kidney [18]. Recently, the frequent inactivation of sFRP1 was also reported in HCC [19, 20]. However, the functional role of sFRP1 in HCC invasion during cancer metastasis is still unknown.

In the current study, we analyzed the promoter methylation profiles of sFRP1 in clinical HCC materials and cell lines. We also observed methylation-associated silencing of the sFRP1 gene frequently occurred by promoter hypermethylation in HCC cell lines. Restoration of sFRP1 in HCC cells leads to a significant reduction in cell invasion, suggesting a potential role of sFRP1 as a tumor suppressor.

\section{Materials and Methods}

Tissue specimens. Fresh samples of HCC tissues were obtained from those patients who underwent curative surgical resection for hepatocellular carcinoma at the First Affiliated Hospital of Zhengzhou University (Zhengzhou, China). None of the patients has received any preoperative treatment. All procedures were explained verbally and in a written consent form. The primary tumor specimens were frozen in liquid nitrogen immediately. Both tumor and adjacent non-tumor tissues were sampled, with approximate $1 \mathrm{~cm}^{3}$ size of each specimen, and were confirmed by pathological examination.

Cell lines and cell culture. Four HCC cell lines (HepG2, SNU398, SK-Hep1 and Hep3B) were obtained from the Cell Bank of Type Culture Collection of Chinese Academy of Sciences (Shanghai, China). All of these cell lines were grown in RPMI1640 (Gibco, Grand Island, NY, USA) supplemented with $10 \%$ fetal bovine serum (Hyclone, Lorgan, UT, USA) and antibiotics (100 U/ml penicillin and $100 \mathrm{mg} / \mathrm{ml}$ streptomycin) at $37^{\circ} \mathrm{C}$ in a humidified $5 \% \mathrm{CO}_{2}$ incubator.

Extraction of genomic DNA and total RNA. Genomic DNA was extracted from the HCC tissues and cells using the DNeasy Tissue Kit (Qiagen, Valencia, CA, USA) according to the manufacturer's recommendation. Total RNA was prepared using Trizol reagent (Life Technologies, Inc., Gaithersburg, MD, USA) according to the manufacturer's instruction. Total RNA concentration and quantity were assessed by absorbency at $260 \mathrm{~nm}$ using a DNA/Protein Analyzer (DU 530, Beckman Instruments, Inc., Fullerton, CA, USA).

RT-PCR. Four micrograms of total RNA were used to synthesize the first strand of cDNA using cDNA Synthesis Kit (Fermentas, Burlington, ON, Canada). GAPDH was used to ascertain the equal amount of cDNA in each reaction. sFRP1 primers used in this study are as follows: sFRP1: 5'-TCCCTGTGACAACGAG-3' (forward) and 5'-GTCCTTCTTCTTGATGGGC-3' (reverse). A total of 30 cycles were performed with each cycle consisting of $30 \mathrm{~s}$ at $94{ }^{\circ} \mathrm{C}$, $35 \mathrm{~s}$ at $64{ }^{\circ} \mathrm{C}$, and $40 \mathrm{~s}$ at $71^{\circ} \mathrm{C}$ with an initial denaturation of $5 \mathrm{~min}$ at $95^{\circ} \mathrm{C}$ and a final extension of $7 \mathrm{~min}$ at $72{ }^{\circ} \mathrm{C}$. The reaction products were separated on $2 \%$ agarose gel and analyzed by an imaging system.

Methylation specific PCR. Bisulfite treatment of genomic DNA was performed as described [21]. The final volume of bisulfite treated DNA for each sample was $20 \mu \mathrm{l}$, and all bisulfite treated DNA was stored at $-20^{\circ} \mathrm{C}$. Methylation was analyzed by using methylation-specific polymerase chain reaction (MSP). MSP primers were designed according to genomic sequences skirting the presumed transcription start sites. MSP primers for unmethylated sFRP1 were 5'-GAGTTAGTGTTGTGTGTTTGTTGTTTTGT-3'(forword).

TTTTGT-3' (forward) and 5'-CCCAACATTACCCAACTCCACAACCA-3' (reverse); MSP primers for methylated sFRP1 were 5'-GTGTCGCGCGTTCGTCGTTTCGC-3' (forward) and 5'-AACGTTACCCGACTC CGCGACCG-3'(reverse). Each MSP reaction was run in a volume of $25 \mu$ l. containing approximately $100 \mathrm{ng}$ of bisulfite-treated DNA, 25 pmoles of each primer, 100 pmoles of dNTPs, 10X PCR buffer, and 1 unit of JumpStart Red Taq Polymerase (Sigma Aldrich, St. Louis, MO, USA). Cycle conditions were performed as follows: $95^{\circ} \mathrm{C}$ x 5 min; 35 cycles $x\left(95^{\circ} \mathrm{C}\right.$ x $30 \mathrm{sec}, 60^{\circ} \mathrm{C}$ x $30 \mathrm{sec}, 72^{\circ} \mathrm{C}$ x $\left.30 \mathrm{sec}\right)$; $72{ }^{\circ} \mathrm{C} \times 5 \mathrm{~min}$. MSP products were analyzed using $2 \%$ agarose gel and analyzed by an imaging system.

Treatments with 5-aza-20-deoxycytidine. Four hepatocellular carcinoma cell lines (HepG2, SNU398, Hep3B and SK-Hep1) were treated with 5-aza-20-deoxycytidine (5AzadC, Sigma Aldrich) based on their hypermethylation profiles. Cells were exposed continuously to $5 \mathrm{Aza}-\mathrm{dC}(5 \mu \mathrm{M})$ for 5 days based on our previous observations that treatment of these cell lines with $5 \mathrm{Aza}-\mathrm{dC}(5 \mu \mathrm{M})$ for 5 days results in the re-expression of genes silenced by aberrant promoter methylation without evidence of excessive cell death.

Cell culture and transfection. All HCC cell lines were grown at $37^{\circ} \mathrm{C}$ in RPMI 1640 supplemented with $10 \%$ fetal bovine serum, in a $5 \% \mathrm{CO}_{2}$ humidified chamber. To establish the stable HepG2 cell line with exogenous sFRP1, the recombinant plasmids pcDNA3.1 containing full-length ORF of sFRP1 and empty vectors as control were transfected into HepG2 cells using FuGENE 6 (Roche Applied Science, Indianapolis, IN, USA) according to the manufacturer's protocol. Then G418 (Life Technologies, Inc., Paisley, UK) was added to the medium at a final concentration of $800 \mu \mathrm{g} / \mathrm{ml}$. After 3-4 weeks, the remaining colonies were individually picked and expanded. The expression of exogenous sFRP1 was detected by western blotting. All experiments were independently repeated at least three times.

Invasion assay. The Matrigel coated Boyden chamber (BD Biosciences, San Jose, CA, USA) was used to evaluate the cell invasion of HepG2 cells. Cells stably transfected with pcDNA3.1-sFRP1 or empty vector were applied onto the upper compartment of invasion chamber coated with Matrigel (30mg/filter). The lower compartment was filled with complete medium. The chamber was incubated at $37^{\circ} \mathrm{C}$ for $12 \mathrm{~h}$ and the filters were removed. Cells invaded on the bottom of inserts were fixed, stained, and counted under a microscope. The value 


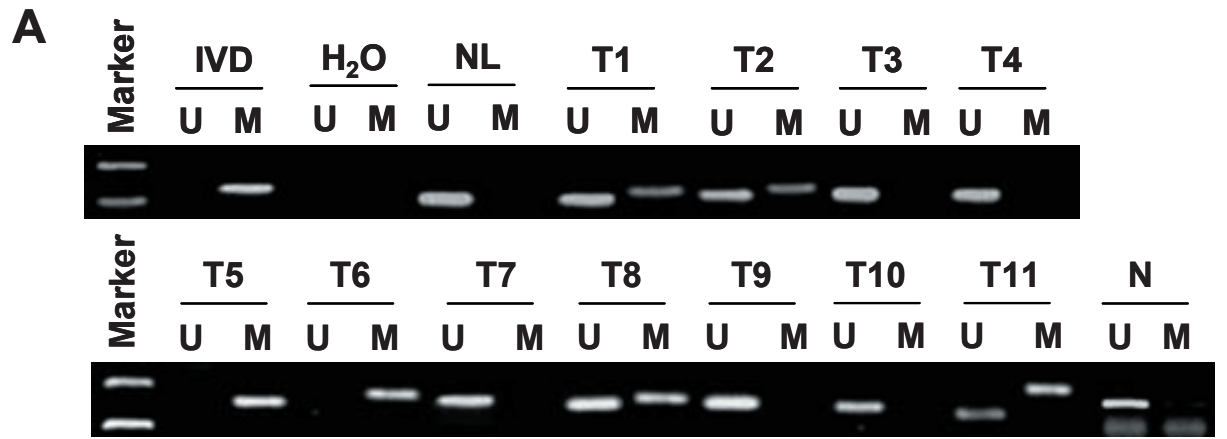

B

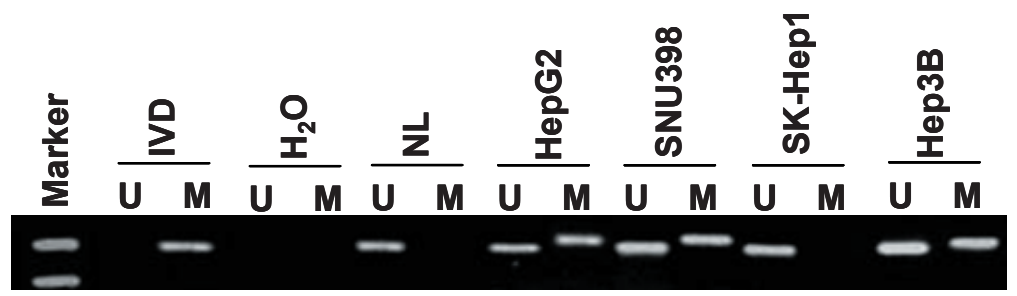

Figure 1. Representative examples of MSP analysis for sFRP1 methylation in hepatocellular carcinoma tissues (A) and cell lines (B). Bisulfitemodified DNA was amplified using MSP primers specific to a $\mathrm{CpG}$ rich region of each gene promoter. PCR-amplified products were resolved by $2 \%$ of agarose gel electrophoresis. (U) Lanes represent amplification of unmethylated alleles, and (M) lanes contain only methylated alleles. In vitro methylated DNA (IVD) and normal human peripheral lymphocytes (NL) served as the positive and negative methylation controls, respectively. T, hepatocellular carcinoma tissues (line T1 through T11); N, normal liver tissue.

of invasion activity was expressed as the average number of invaded cells per microscopic field over the 5 fields in each assay from four independent experiments.

Transient transfection and luciferase assay. Luciferase assays to determine transcriptional activity were performed as previously reported [22]. pGL3-OT (TCF/LEF-responsive reporter), pGL3-OF (negative control with mutated TCF/LEF binding site) and the pRL-TK internal control vector were purchased from Promega (Madison, WI). Briefly, HepG2 cells stably

Table 1. Correlation between methylation status and clinicopathological parameters in $\mathbf{5 3}$ hepatocellular carcinoma tissues.

\begin{tabular}{|c|c|c|c|}
\hline \multirow{2}{*}{ Characteristics } & $\mathrm{U}(21)$ & $\mathrm{M}(32)$ & \multirow{2}{*}{$\begin{array}{c}p \text {-value } \\
(p<0.05)\end{array}$} \\
\hline & \multicolumn{2}{|c|}{$60 \% *$} & \\
\hline \multicolumn{4}{|l|}{ Sex } \\
\hline Male & 12 & 15 & NS \\
\hline Female & 9 & 17 & \\
\hline \multicolumn{4}{|l|}{$\mathrm{HBV}$} \\
\hline+ & 14 & 13 & NS \\
\hline- & 7 & 19 & \\
\hline \multicolumn{4}{|l|}{ Size } \\
\hline$\leq 3 \mathrm{~cm}$ & 8 & 14 & NS \\
\hline$>3 \mathrm{~cm}$ & 13 & 18 & \\
\hline \multicolumn{4}{|c|}{ Pathological grade } \\
\hline I / П & 9 & 16 & NS \\
\hline Ш / IV & 12 & 16 & \\
\hline
\end{tabular}

transfected with pcDNA3.1-sFRP1 or empty vector were plated in 24 -well culture plates $\left(5 \times 10^{4}\right.$ cells/well). Cells were transiently cotransfected with pGL3-OT, pGL3-OF, pRL-TK control vector. After $48 \mathrm{~h}$ transfection, luciferase activities were measured using a Dual-Luciferase Reporter Assay system (Promega). Firefly luciferase values were standardized to renilla values. For each experiment, the luciferase assay was performed three times.

Statistical analysis. Statistical analysis was performed with SPSS10.0 software. Data were expressed as means \pm SEM. Student's t-test was used for statistical comparison. A value of $p<$ 0.05 was considered to be statistically significant.

\section{Results}

Methylation analysis of sFRP1 in HCC tissues and cell lines. MSP was used to examine the methylation status of sFRP1 in hepatocellular carcinoma tissues and cell lines. Representative examples of the MSP analysis were shown in Figure 1A, expectedly, hypermethylation was found in 32 $(60 \%)$ of 53 HCC tumor tissues, but not in normal liver tissue. $21(65.6 \%)$ of them showed both methylated and unmethylated DNA PCR products. Statistically, there was no significant relationship between hypermethylation and clinicopathological parameters, including tumor size, hepatitis virus type, and pathological grade (Table 1). We further analysed methylation profile of sFRP1 in a panel of hepatocellular carcinoma cell lines (HepG2, SNU398, SK-Hep1 and Hep3B). MSP analysis showed that both methylated and unmethylated DNA PCR 
products were observed in SNU398, Hep3B and HepG2 cells. However, no methylation PCR products were detected for sFRP1 in SK-Hep1 cells (Figure 1B).

Restored or increased sFRP1 expression in HepG2, SNU398 and Hep3B cells after 5-Aza-dC treatment. To assess the possible correlation between sFRP1 expression and its promoter hypermethylation, the demethylation chemical, 5-Aza-dC was used in these four cell lines, and measured the expression of sFRP1 by RT-PCR. As shown in Figure 2, sFRP1 expression were increased or restored after treatment with 5-Aza-dC. These results strongly implicated that hypermethylation of this gene promoter was closely related to the absent or decreased this gene expression.

Exogenous sFRP1 suppresses HCC cell invasion. To assess whether sFRP1 silencing could contribute to HCC invasiveness and metastatic behavior, plasmid pcDNA3.1 with full ORF of sFRP1 (pcDNA3.1 sFRP1) was transfected into HepG2 cells, in which endogenous expression is silenced by DNA hypermethylation, where the empty vector pcDNA3.1 was used as control. Cells invasion was determined through Matrigel coated polycarbonate filter in the Boyden chamber system. As shown in Figure 3A and 3B, exogenous sFRP1 markedly inhibited $(p<0.05)$ the invasion of HepG2 cells as compared

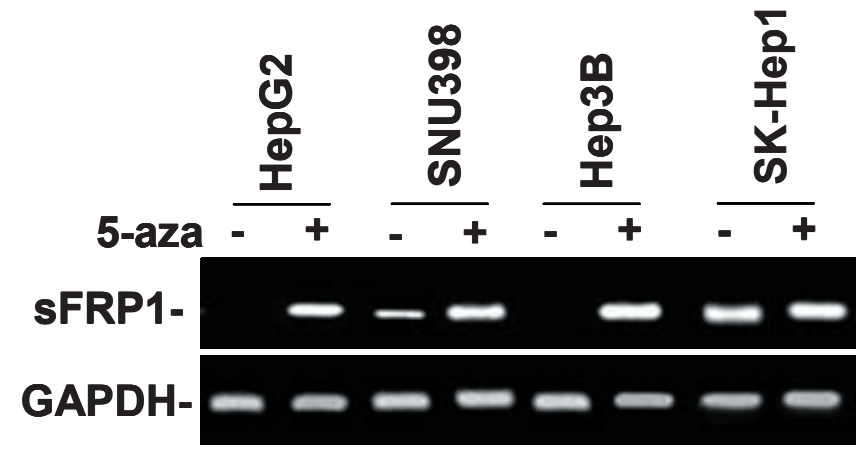

Figure 2. RT-PCR analysis of sFRP1 mRNA expression in HCC cell lines before and after 5 -aza-dC treatment. Cells were exposed continuously to 5 Aza-dC $(5 \mu M)$ for 5 days. PCR-amplified products were resolved by $2 \%$ of agarose gel electrophoresis.

to the empty vector and HepG2 cell control, respectively. The protein levels of sFRP1 greatly increases $(p<0.05)$ in sFRP1 transfectants by Western blots (Figure $3 \mathrm{C}$ ). These results reveal that $\mathrm{sFRP1}$ could play an important roles in regulating the invasion of HCC-derived cells.

A
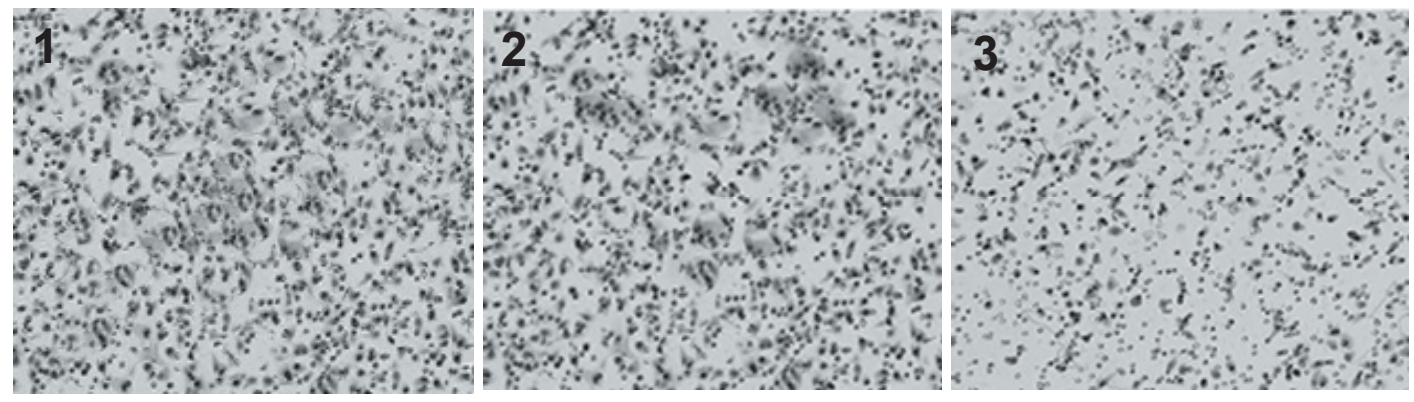

B 응
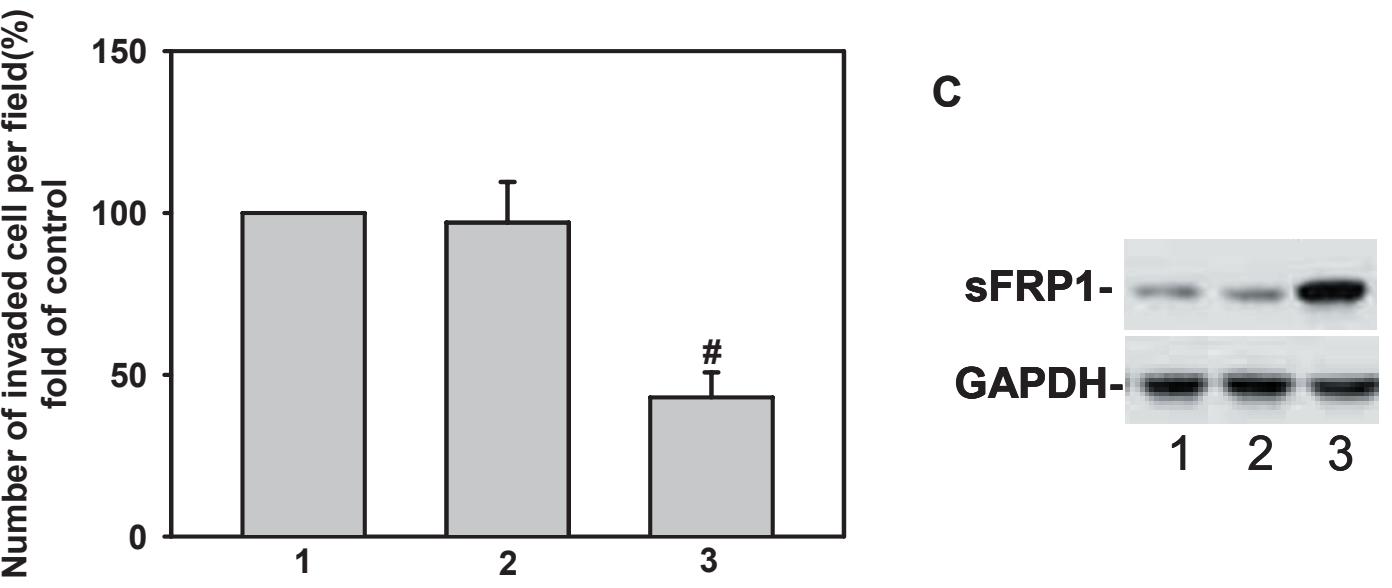

Figure 3. Effects of exogenous sFRP1 on HepG2 cell invasion by transwell chamber assay. HepG2 pcDNA3.1-sFRP1 cells and control cells were overlaid in the upper chambers of 24-well tissue culture plates. After incubation for $24 \mathrm{~h}$, penetrating cells were fixed and stained with $0.1 \% \mathrm{crystal}$ violet. (A) photographs are depicted invasion of HepG2 cells (1) HepG2 pcDNA3.1 cells (2) HepG2 pcDNA3.1 sFRP1 cells (3). (B) Quantified data are expressed as means \pm SEM from four independent experiments. ${ }^{*}$ differ $(p<0.05)$ from HepG2 control and HepG2 pcDNA3.1. (C) Western blot analysis of sFRP1 expression in HepG2 pcDNA3.1 sFRP1 cells and control cells 


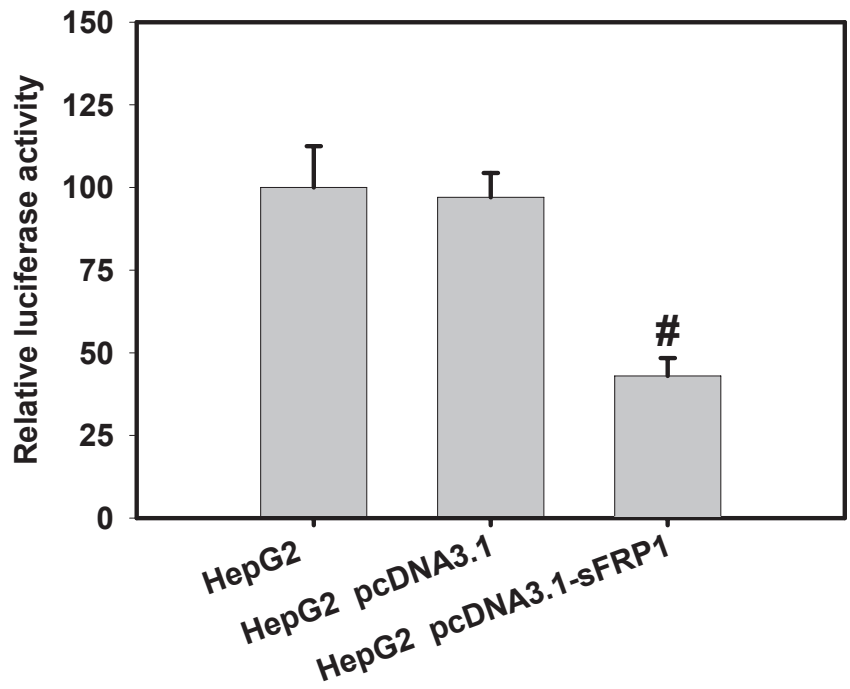

Figure 4. Exogenous sFRP1 inhibits $\beta$-catenin/T-cell factor-dependent transcription activity in HepG 2 cells. Activity of the $\beta$-catenin/TCF-driven transcription was measured using Luciferase assays. HepG2 pcDNA3.1 sFRP1 cells and control cells were seeded on 24-well plates and transiently co-transfected with reporter plasmids and pRL-TK control plasmid. Luciferase activities were measured $\mathbf{4 8}$ hours later with a luminometer. Firefly luciferase values were standardized to renilla values. Data were expressed as means \pm SEM fold of HepG2 control and "differ $(p<0.05)$ from HepG2 control and HepG2 pcDNA3.1.

$\beta$-catenin/T-cell factor-dependent transcription activity was inhibited by exogenous sFRP1 in HepG2 cells. To further explore sFRP1 function on $\beta$-catenin activation of downstream gene, luciferase reporter assay was performed in HepG2 cell transfected with pcDNA3.1 sFRP1 and pcDNA3.1. Our results showed a significant decrease $(p<0.05)$ of $\beta$-catenin/T-cell factor-dependent transcription activity in the sFRP1 restoration cells in comparison with controls (Figure 4), confirming that exogenous sFRP1 expression reduces canonical pathway activity in HepG2 cells. These results also revealed that SFRP1 as a Wnt pathway antagonist could negatively regulate the HCC cell invasion through inactivation of Wnt- $\beta$-catenin pathway.

\section{Discussion}

Epigenetic silencing due to aberrant methylation of $\mathrm{CpG}$ islands has been ascertained as one of the major genetic alterations in cancer development and progression, including HCC [23]. Clinically, the identification of genes with abnormal methylation and consequently become silenced is of critical importance since this provides us a source of new valuable cancer markers and potential therapeutic targets [24].

Aberrant methylation of the sFRP1 promoter is widely studied in various types of human cancer. sFRP1 suppression has been observed in gastric cancer [15], colon tumor [17], kidney tumor [18] and HCC [19]. Consistent with previous reports, our present result indicated that similar incidence of promoter hypermethylation of sFRP1 was documented in HCC tissue and cell lines. It is noteworthy that $60 \% \mathrm{sFRP} 1$ promoter methylation in HCC tissues were detected in the current study, which is a little higher than that in previous reports $(\sim 48 \%)[25,26]$, this discrepancy might be due to the different $\mathrm{CpG}$ sites and the sensitivity of MSP methods. Statistically, there was no relationship between hypermethylation and clinicopathologic parameters, including tumor size, hepatitis virus type, and pathological grade. Furthermore, 5-Aza-dC, a widely used demethylating drug, was able to restore or increase sFRP1 expression in HepG2, SNU398 and Hep3B cells. These results suggested significant correlation between promoter hypermethylation and gene transcription in these HCC cell lines.

Increasing evidences have indicated that sFRP1 could control the growth of different types of cancer cells including cervical [27], lung [28], and oral squamous cell carcinoma cells [29] in culture. This inhibitory effect was also demonstrated in HCC cell lines in vitro [30]. However, whether the silencing of sFRP1 could contribute to HCC cell invasion and metastasis remains unknown. In the current study, our data indicated that sFRP1 performed a negative regulator in the cell invasion of HCC cells. The restoration of sFRP1 can significantly inhibit the cell invasion of HepG2 cells, suggesting the significant epigenetic silencing of sFRP1 could contribute to oncogenesis of HCC through promoting cell invasion. On the other hand, our data also revealed that sFRP1 as a tumor suppressor gene could be implicated for cancer therapy.

Various studies demonstrated the role of constitutively active $W n t / \beta$-catenin signaling in tumor progression $[31,32]$. sFRP1 functionally acts as Wnt signaling inhibitors, when it is silenced by promoter hypermethylation, which leads to nuclear accumulation of $\beta$-catenin and forms a complex with members of the T-cell factor/ lymphocyte enhanced factor, subsequently up-regulates of downstream target genes, which are involved in cell growth and cell invasion $[33,34]$. In the present study, we assessed whether restoration of sFRP1 is associated with the inactivation of the $\beta$-catenin signaling pathway. Our data indicated that exogenous sFRP1 caused significant decrease of $\beta$-catenin/T-cell factor-dependent transcription activity, suggesting the potential role of $\mathrm{Wnt} / \beta$-catenin signaling in tumor progression, especially for tumor metastasis.

In conclusion, we have clearly shown the methylation status of sFRP1 genes in HCC tissues and cell lines, the downregulation of sFRP1 as a candidate of tumor suppressor gene, triggered by the epigenetic events and could contribute to the oncogenesis of HCC. Restoration of sFRP1 in HCC cells leads to a significant reduction in cell invasion. This would be an opportunity to prevent the development and progression of HCC through regulation of sFRP1.

\section{References}

[1] PARKIN DM, BRAY F, FERLAY J, PISANI P. Global cancer statistics, 2002. CA Cancer J Clin 2005; 55: 74-108. http:// dx.doi.org/10.3322/canjclin.55.2.74 
[2] ASIM M, MALIK A, SARMA MP, POLIPALLI SK, BEGUM $\mathrm{N}$, et al. Hepatitis B virus BCP, Precore/core, $\mathrm{X}$ gene mutations/genotypes and the risk of hepatocellular carcinoma in India. J Med Virol. 2010; 82: 1115-1125. http://dx.doi. org/10.1002/jmv.21774

[3] DAVILA JA, MORGAN RO, SHAIB Y, MCGLYNN KA, EL-SERAG HB. Hepatitis $C$ infection and the increasing incidence of hepatocellular carcinoma: a population-based study. Gastroenterology 2004; 127: 1372-1380. http://dx.doi. org/10.1053/j.gastro.2004.07.020

[4] WANG JS, HUANG T, SU J, LIANG F, WEI Z, et al. Hepatocellular carcinoma and aflatoxin exposure in Zhuqing Village, Fusui County, Peopless Republic of China. Cancer Epidemiol Biomarkers Prev 2001; 10: 143-146.

[5] HASEGAWA K, KOKUDO N. Surgical treatment of hepatocellular carcinoma. Surg Today. 2009; 39: 833-843. http://dx.doi. org/10.1007/s00595-008-4024-Z

[6] SHARIFF MI, COX IJ, GOMAA AI, KHAN SA, GEDROYC W, et al. Hepatocellular carcinoma: current trends in worldwide epidemiology, risk factors, diagnosis and therapeutics. Expert Rev Gastroenterol Hepatol. 2009; 3: 353-367. http://dx.doi. org/10.1586/egh.09.35

[7] PRUNIER C, HOCEVAR BA, HOWE PH. Wnt signaling: physiology and pathology. Growth Factors. 2004; 22: 141-150. http://dx.doi.org/10.1080/08977190410001720860

[8] HERBST A, KOLLIGS FT. Wnt signaling as a therapeutic target for cancer. Methods Mol Biol. 2007;361:63-91.

[9] RUBIN JS, BARSHISHAT-KUPPER M, FEROZE-MERZOUG F, XI ZF. Secreted WNT antagonists as tumor suppressors: pro and con. Front Biosci. 2006; 11: 2093-2105. http://dx.doi. org/10.2741/1952

[10] ZHANG Y, HUANG S, DONG W, LI L, FENG Y, et al. SOX7, down-regulated in colorectal cancer, induces apoptosis and inhibits proliferation of colorectal cancer cells. Cancer Lett. 2009; 277: 29-37. http://dx.doi.org/10.1016/j.canlet.2008.11.014

[11] VALENCIA A, ROMAN-GOMEZ J, CERVERA J, SUCH E, BARRAGAN E, et al. Wnt signaling pathway is epigenetically regulated by methylation of Wnt antagonists in acute myeloid leukemia. Leukemia. 2009; 23: 1658-1666. http://dx.doi. org/10.1038/leu.2009.86

[12] HU J, DONG A, FERNANDEZ-RUIZ V, SHAN J, KAWA M, et al. Blockade of Wnt signaling inhibits angiogenesis and tumor growth in hepatocellular carcinoma. Cancer Res. 2009; 69: 6951-6959. http://dx.doi.org/10.1158/0008-5472.CAN-09$\underline{0541}$

[13] DAHL E, WIESMANN F, WOENCKHAUS M, STOEHR R, WILD PJ, et al. Frequent loss of SFRP1 expression in multiple human solid tumours: association with aberrant promoter methylation in renal cell carcinoma. Oncogene 2007;26:56805691. http://dx.doi.org/10.1038/sj.onc.1210345

[14] FINCH PW, HE X, KELLEY MJ, UREN A, SCHAUDIES RP, et al. Purification and molecular cloning of a secreted, frizzled-related antagonist of Wnt action. Proc Natl Acad Sci USA. 1997; 94: 6770-6775. http://dx.doi.org/10.1073/ pnas.94.13.6770

[15] CHENG YY, YU J, WONG YP, MAN EP, TO KF, et al. Frequent epigenetic inactivation of secreted frizzled-related protein 2
(SFRP2) by promoter methylation in human gastric cancer. Br J Cancer 2007; 97: 895-901.

[16] FUKUI T, KONDO M, ITO G, MAEDA O, SATO N, et al.Transcriptional silencing of secreted frizzled related protein 1 (SFRP 1) by promoter hypermethylation in non-small-cell lung cancer. Oncogene. 2005; 24: 6323-6327. http://dx.doi. org/10.1038/sj.onc. 1208777

[17] SUZUKI H, WATKINS DN, JAIR KW, SCHUEBEL KE, MARKOWITZ SD, et al. Epigenetic inactivation of SFRP genes allows constitutive WNT signaling in colorectal cancer. Nat Genet 2004; 36: 417-422. http://dx.doi.org/10.1038/ $\underline{\text { ng1330 }}$

[18] KAWAKAMI K, YAMAMURA S, HIRATA H, UENO K, SAINI S, et al. Secreted frizzled-related protein-5 is epigenetically downregulated and functions as a tumor suppressor in kidney cancer. Int J Cancer. 2011; 128: 541-550. http://dx.doi. org/10.1002/ijc.25357

[19] TAKAGI H, SASAKI S, SUZUKI H, TOYOTA M, MARUYAMA R, et al. Frequent epigenetic inactivation of SFRP genes in hepatocellular carcinoma. J Gastroenterol. 2008; 43: 378-389. http://dx.doi.org/10.1007/s00535-008-2170-0

[20] BENGOCHEA A, DE SOUZA MM, LEFRANCOIS L, LE ROUX E, GALY O, et al. Common dysregulation of Wnt/Frizzled receptor elements in human hepatocellular carcinoma. Br J Cancer. 2008; 99: 143-150. http://dx.doi.org/10.1038/ sj.bjc. 6604422

[21] GRUNAU C, CLARK SJ, ROSENTHAL A. Bisulfite genomic sequencing: systematic investigation of critical experimental parameters. Nucleic Acids Res. 2001; 29: E65-5. http://dx.doi. org/10.1093/nar/29.13.e65

[22] ZHANG W, GLOCKNER SC, GUO M, MACHIDA EO, WANG DH, et al. Epigenetic inactivation of the canonical Wnt antagonist SRY-box containing gene 17 in colorectal cancer. Cancer Res. 2008; 68: 2764-2772. http://dx.doi. org/10.1158/0008-5472.CAN-07-6349

[23] VUCIC EA, BROWN CJ, LAM WL Epigenetics of cancer progression. Pharmacogenomics 2008; 9: 215-234 http://dx.doi. org/10.2217/14622416.9.2.215

[24] ESTELLER M Epigenetic gene silencing in cancer the DNA hypermethylome. Hum Mol Genet 2007; 16:R50-9 http:// dx.doi.org/10.1093/hmg/ddm018

[25] HUANG J, ZHANG YL, TENG XM, LIN Y, ZHENG DL, et al. Down-regulation of SFRP1 as a putative tumor suppressor gene can contribute to human hepatocellular carcinoma. BMC Cancer. 2007; 12; 7:126.

[26] SHIH YL, SHYU RY, HSIEH CB, LAI HC, LIU KY, et al. Promoter methylation of the secreted frizzled-related protein 1 gene SFRP1 is frequent in hepatocellular carcinoma. Cancer. 2006; 107: 579-590. http://dx.doi.org/10.1002/cncr.22023

[27] CHUNG MT, LAI HC, SYTWU HK, YAN MD, SHIH YL, et al. SFRP1 and SFRP2 suppress the transformation and invasion abilities of cervical cancer cells through Wnt signal pathway. Gynecol Oncol. 2009; 112: 646-653. http://dx.doi. org/10.1016/j.ygyno.2008.10.026

[28] FUKUI T, KONDO M, ITO G, MAEDA O, SATO N, et al. Transcriptional silencing of secreted frizzled related protein 1 (SFRP 1) by promoter hypermethylation in non-small-cell 
lung cancer. Oncogene. 2005; 24: 6323-6327. http://dx.doi. org/10.1038/sj.onc. 1208777

[29] SOGABE Y, SUZUKI H, TOYOTA M, OGI K, IMAI T, et al. Epigenetic inactivation of SFRP genes in oral squamous cell carcinoma. Int J Oncol. 2008; 32: 1253-1261.

[30] SHIH YL, HSIEH CB, LAI HC, YAN MD, HSIEH TY, et al. SFRP1 suppressed hepatoma cells growth through Wnt canonical signaling pathway. Int J Cancer. 2007; 121: 1028-1035. http://dx.doi.org/10.1002/ijc.22750

[31] YING Y, TAO Q. Epigenetic disruption of the WNT/betacatenin signaling pathway in human cancers. Epigenetics. 2009; 4: 307-312. http://dx.doi.org/10.4161/epi.4.5.9371
[32] PAUL S, DEY A. Wnt signaling and cancer development: therapeutic implication. Neoplasma. 2008;55:165-176.

[33] ROMAN-GOMEZ J, CORDEU L, AGIRRE X, JIMENEZ-VELASCO A, SAN JOSE-ENERIZ E, et al. Epigenetic regulation of Wnt-signaling pathway in acute lymphoblastic leukemia. Blood. 2007; 109: 3462-3469. http://dx.doi.org/10.1182/blood2006-09-047043

[34] KAWANO Y, DIEZ S, UYSAL-ONGANER P, DARRINGTON RS, WAXMAN J, et al. Secreted Frizzled-related protein-1 is a negative regulator of androgen receptor activity in prostate cancer. Br J Cancer. 2009; 100: 1165-1174. http://dx.doi. org/10.1038/sj.bjc. 6604976 